\title{
Introducing Female Condoms to Female Sex Workers In Central America
}

\begin{abstract}
CONTEXT: Female condoms have a potential role in reducing HIV infection among female sex workers in Central America. Research on how to introduce female condoms to this population is warranted.
\end{abstract}

METHODS: Two rounds of focus groups with sex workers (115 in round one and 81 in round two) were conducted in El Salvador and Nicaragua in 2007-2008. In addition, we conducted structured interviews with 95 sex workers and direct observations of six health educators.

RESULTS: Women reported that the design of the female condom made insertion and removal difficult to learn. About one-third of participants reported inserting it for the first time alone. Most women reported practicing 2-10 times before feeling skilled enough to use it with partners. Positive perceptions included lubrication, size, comfort and strength. Negative perceptions included the large package, initial physical discomfort and the possibility that the device would scare clients away. The participants preferred to learn to use female condoms from an instructional brochure plus instructor-led training in their workplace. They cited lack of exposure to female condoms among men and women as a barrier to female condom use and recommended education for both men and women; they also recommended distribution of female condoms at places where male condoms are available.

CONCLUSIONS: If provisions are made for instructing women on female condom use in places where women will not feel stigmatized, and if supplies are easily and consistently available, uptake of the female condom among female sex workers in Central America seems likely. Health educators' use of promotional tools such as checklists and standardized messages is strongly recommended.

International Perspectives on Sexual and Reproductive Health, 2010,36(3):149-156

The female condom could play an important role in reducing HIV infection among female sex workers and their clients in Central America. Acceptability studies have shown that Central American sex workers are amenable to using the female condom, ${ }^{1-3}$ but programs have not always successfully promoted long-term use. For example, promotional efforts by the Pan American Social Marketing Organization (PASMO) produced different results in different countries in the region: In Nicaragua in 2005, only 300 female condoms were distributed, and program staff reported acceptability to be low. In contrast, almost 12,000 were distributed in El Salvador from 2003 to 2005; once the supply of female condoms had been depleted, sex workers continued to ask when more would be available. ${ }^{4}$

Given that the female condom could increase sex workers' overall number of protected sex acts ${ }^{5-9}$ and protect them from STIs (including HIV) and pregnancy, $6,10-14$ efforts to promote female condoms effectively to this specific target population are needed ${ }^{15}$-especially because exposure to mass-marketing campaigns does not necessarily translate into uptake. ${ }^{16,17}$ To date, successful female condom programs for multiple populations have used provider training; targeted marketing; face-to-face communication with target populations; comprehensive training, including insertion practice and partner negotiation skills; practice with an anatomical model; encouragement; testimonials by satisfied users; integration of female condom use into HIV and STI prevention communications; a sustained supply of female condoms and low-cost distribution through public and private sector channels. ${ }^{18-22}$ To encourage uptake and sustained use, program efforts should place particular emphasis on correct and consistent use of female condoms and partner negotiation skills. ${ }^{12,23,24}$

In order for access and uptake to be sustained over the long term, programs must create and measure demand, ${ }^{18}$ as well as ensure a steady supply of female condoms through the support of governments and donors. ${ }^{25-27} \mathrm{Fe}$ male condoms should also be easily accessible; in countries where the female condom is available, women have been able to obtain the device from pharmacies, hairdressers, HIV and AIDS support groups, and peers, as well as health clinics. ${ }^{27}$

To inform strategies for promoting the female condom to female sex workers in Central America, we conducted formative research with sex workers at three sites in El Salvador and Nicaragua from September 2007 to February 2008. Our implementing partners were PASMO and Mercaplan, Inc. We worked with PASMO staff for site identification, identification of recruitment locations and train-

\section{By Natasha Mack, Thomas G. Grey, Alexis Amsterdam, Nancy Williamson and Claudia Interiano Matta}

Natasha Mack is associate scientist II, Family Health International (FHI), Durham, NC, USA. Thomas G. Grey was research associate I, Alexis Amsterdam was consultant and Nancy Williamson was senior scientist, all at FHI, during the writing of this article. Claudia Interiano Matta is operations manager, Mercaplan Central America, San Pedro Sula, Honduras. 
ing of study staff in demonstrating female condom use. Staff from Mercaplan, Inc., collected the data.

Here we report on sex workers' views of the kinds of instruction, educational materials and communication channels they believe would encourage use of the female condom. We also report on PASMO's current female condom promotion in the study sites, identifying differences among sites and gaps in promotional messaging. We also provide recommendations for strategies and messages that program planners may use to introduce the female condom to the female sex worker population in Central America.

\section{METHODS}

\section{Study Population}

Study participants were 115 female sex workers older than 18 working in Managua, Nicaragua, and San Miguel and San Salvador, El Salvador, who verbally agreed to participate in two rounds of focus groups and one structured interview. Purposive recruitment of female sex workers was conducted at locations where sexual encounters between female sex workers and clients occur. Participants had to self-identify as sex workers, be willing to try the female condom and be planning to stay in the area for two months. Both sex workers in fixed-site settings and those not affiliated with a specific establishment were included. Six health educators from PASMO who regularly worked with female sex workers at the study sites also participated.

\section{Study Design}

The study used qualitative and quantitative methods. Two rounds of semi-structured focus group discussions were conducted with up to 12 female sex workers each, during which the moderator provided training on the female condoms and gave a supply of female condoms to each participant. Numbered illustrations were provided on the package of the female condom. Women were also given an illustrated brochure with written instructions in Spanish. Focus group discussions were conducted in Spanish, taperecorded and transcribed verbatim. The groups were homogeneous by socioeconomic status to encourage women to speak freely. Quantitative data were collected during structured interviews with sex workers. Data collectors also used a checklist during direct observations of health educators to document their promotion of the female condom.

Twelve focus groups were conducted in the first round, with an average of 9.6 participants per group; there were 115 participants in total (40 in San Salvador, 43 in San Miguel and 32 in Managua). Ninety-five structured interviews were conducted, with 36 participants in San Salvador, 37 in San Miguel and 22 in Nicaragua. Eleven focus groups were conducted in the second round, with an average of 7.4 women per group. There were a total of 81 participants in the second round (25 in San Salvador, 31 in San Miguel and 25 in Managua).

In the first round of the focus group discussions, we asked participants to describe their current knowledge, first impressions and past experiences with the female condom.
The focus group moderator then used an anatomical model to demonstrate the proper use of the female condom. Next, we asked women to discuss the circumstances in which they would be most likely to use the female condom, the potential advantages and disadvantages of the female condom, the possibility of using the female condom in situations when they could not use the male condom and the ways in which they might negotiate using the female condom with different types of partners. At the end of the first round of focus group discussions, we gave participants 21 female condoms and asked the participants to use them with the partner or partners of their choice.

Two to four weeks after completing the first round of focus group discussions, the participants met with the focus group moderator individually for a structured interview. A questionnaire was used to collect information that women may not have felt comfortable discussing in a group setting. It was also an opportunity for study participants to ask additional questions about how to use the female condom and to obtain more female condoms. Participants were given the same number of female condoms they had used between the first focus group and the structured interview, typically 15-21.

The questionnaire collected information on age, marital status, education, amount and sources of income, current contraceptive practices, number and types of partners, and length of time involved in sex work. To understand the context of women's male and female condom usage, participants were asked about their knowledge and risk perceptions of STIs and HIV, and their perceptions of the protection male condoms and female condoms provide against STIs, HIV and pregnancy. Participants were asked about their experiences using the sample female condoms distributed during the first round of focus group discussions, including the level of ease or difficulty of insertion and removal, the circumstances in which they had chosen to use the female condom for the first time, the number of female condoms they had used, the ways in which they had introduced the female condom to different types of partners and their partners' reactions to the female condom.

Four to five weeks after the structured interview, a second round of focus group discussions was conducted to discuss participants' experiences using the female condom. Participants discussed their overall impressions of the device, their experiences using it with different types of sexual partners, aids and barriers to use, and suggestions for encouraging use among peers. At the end of their second focus group discussion, women received 21 additional female condoms with no follow-up.

To learn if there were differences in promotion across sites that might explain differences in uptake, study staff conducted structured observations of the reproductive health education sessions of six PASMO health educators to document the ways in which they currently promoted the female condom to groups of sex workers in their place of employment. In San Salvador, one health educator was 
observed twice and two others were observed one time each. Observation sites included one street location, one beauty salon and two brothels. In San Miguel, two health educators were observed for two sessions each. Observation sites included one street location, one nightclub and two brothels. In Managua, four observations were conducted with the same health outreach worker. The four observation sites included one bar and three brothels.

Staff used a checklist to document whether health educators had covered each of 37 topics. Topics included general information about STI, HIV and pregnancy risk; contraceptive methods; counseling and testing information for STIs and HIV; and counseling about the use of male condoms and female condoms.

Prior to study initiation, the study protocol was approved by the institutional review boards of Abt Associates and Family Health International, as well as by the Ministries of Health of El Salvador and Nicaragua.

\section{Data Analysis}

Transcripts were analyzed using the qualitative data analysis software QSR NVivo 7.0. Transcripts were coded according to question, research objective and emergent themes. Structured interview questionnaires were completed by hand, entered into Epi Info Version 6.04d DOS software files and analyzed quantitatively using SAS 9.1 for Windows. Responses to open-ended questions were coded using a spreadsheet and then entered into the SAS database for analysis. Direct observations of health educators were recorded on-site by hand, entered into electronic files and analyzed by hand.

\section{RESULTS}

\section{Sample Characteristics}

The 95 structured interview participants had generally similar demographic characteristics across the three study sites (Table 1 ). The median age across sites was 26 , the median number of children was three and the median number of years of education was seven. Women with the highest socioeconomic status were the youngest (median age, 22), while women with the lowest socioeconomic status were the oldest (median age, 31; not shown).

Overall, the median age at which the respondents had started sex work was 19. About one-third of the women had employment in addition to sex work (not shown), with women in Managua being the least likely to have other work. Across sites, women in the highest socioeconomic group were least likely to have additional employment. Women in San Miguel reported earning more money per month than women in other sites (Table 1) and were more likely to report having other jobs. Women in the highest socioeconomic group earned approximately twice as much as those in the lowest (not shown).

Contraceptive use among study participants was high. It was 77\% among women in Managua, where prevalence was lowest, but almost universal among the participants in El Salvador. About one-quarter of women reported
TABLE 1. Selected characteristics of female sex workers participating in focus group discussions on the female condom in EI Salvador and Nicaragua, 2007-2008

Characteristic

\begin{tabular}{l|l|l} 
All & El Salvador & Nicaragua
\end{tabular}

\begin{tabular}{lc|cc|c}
\cline { 2 - 5 } & $(\mathrm{N}=95)$ & \multicolumn{2}{|c|}{$\begin{array}{l}\text { San Salvador San Miguel } \\
(\mathrm{N}=36)\end{array}$} & $\begin{array}{l}\text { Managua } \\
(\mathrm{N}=37)\end{array}$ \\
\hline Median age & $26(18-51)$ & $27(18-41)$ & $26(18-51)$ & $27(19-48)$ \\
Median no. of children & $3(1-9)$ & $3(1-4)$ & $3(1-9)$ & $3(1-6)$ \\
Median yrs. of education & $7(0-14)$ & $8(0-14)$ & $6(0-12)$ & $7(0-14)$ \\
Median age when started sex work & $19(12-40)$ & $20(14-30)$ & $19(14-40)$ & $19(12-37)$ \\
Median monthly income* (in US\$) & $\$ 360$ & $\$ 309$ & $\$ 507$ & $\$ 200$ \\
Monthly income range (in US\$) & $\$ 28-\$ 1,500$ & $\$ 100-1,100$ & $\$ 100-1,500$ & $\$ 28-\$ 499$ \\
Any contraceptive use (\%) & 93 & 94 & 100 & 77 \\
\hline
\end{tabular}

*Includes all forms of income. Note: Figures in parentheses are ranges.

using the male or female condom to prevent pregnancy (not shown). Almost one-third of women in San Salvador reported that they had been sterilized. Sterilization was also common in San Miguel, but not in Managua.

Only one study participant reported that she had not heard of STIs and HIV. Most women in the two El Salvador sites reported that they were very worried about contracting HIV, but thought it was completely within their control to protect themselves from infection. Fewer women in Managua held these beliefs; about three-quarters of participants were very worried about HIV infection, but only half believed that STI protection was completely within their control.

\section{Initial Insertions of the Female Condom}

All but one of the participants in the structured interviews reported inserting at least one female condom between the first focus group discussion and the structured interview 2-4 weeks later. By the time of the second round of focus group discussions, participants had used an average of 12 of the 21 female condoms they had received during the first round; overall, approximately 1,140 female condoms were used during that interval.

Women reported that the female condom's design made it difficult to insert and remove. Compared with women from the other sites, a higher proportion of women from Managua reported they found female condom insertion difficult.

Before trying the female condom, several women said they thought it would be hard (or impossible) to insert, and after trying the female condom, they still felt that way. As two participants explained:

"I spent about an hour. I didn't leave the bathroom." -Managua, round 2

"It bothers you the first time. It's complicated because one doesn't know and they don't explain how to put it inwhat stays inside and what stays outside. The first time, it is really hard to insert the part that stays inside."-San Salvador, round 1

Women had negative initial reactions to the internal ring, which they said caused physical discomfort during insertion, while the female condom was inside and during 
removal. For example, one woman said:

"The internal ring is what bothered me. At first and up to the fifth time. I said to myself, "When will this stop hurting me?' I felt a lot of discomfort."-Managua, round 2

Almost one-third of participants who responded to the question (28 of 94) said they tried the female condom alone for practice the first time they inserted it. In the focus group discussions, most respondents said that women should practice on their own to get accustomed to insertion and removal. They reported needing to practice 2-10 times before they felt skilled enough to use it with a partner. Women recommended that more training be given on how to use the female condom, since it was hard to learn to use it on one's own. Despite their initial difficulties, nearly all participants said that once they had gotten used to it, the female condom was easy to insert and comfortable to use.

Participants reported that it took time to decide whether they liked the female condom. When asked how long it took to decide, the majority reported 3-10 uses. After trying the female condom during the interval between the first round of focus group discussions and the structured interview, slightly more than half (52 out of 94) of all responding participants said they preferred the female condom to the male condom. About one in nine said that it depended on the type of partner (not shown).

\section{Impressions of the Female Condom}

One positive attribute of the female condom that women cited was comfort for both women and men because the female condom was well lubricated. They said that this made it less likely to break, precluded the need to purchase extra lubricant and made the female condom less irritating than the male condom. Women complained that because of the dryness of the male condom, they got urinary tract infections and irritation like burning and scraping. For example, one participant commented:

"It doesn't irritate you. When you have a dry vagina, the [male] condom breaks or it scratches you and you have to use lubricant. With this one, you don't have to."-Managua, round 2

Some women reported that they and their partners felt as though they were not using a condom at all when they used the female condom:

"If there are clients who don't want to use the male condom, now we can protect ourselves with the female condom. And it feels good because there are clients who say that they don't feel anything." -San Miguel, round 2

Women described the large size as able to accommodate all penis sizes, reducing the risk of condom breakage and slippage and permitting use when the man's penis was not erect. Women appreciated being able to insert the female condom ahead of time because this would enable them to ensure that they would be protected with men who would not use male condoms. One participant stated:

*Bleeding, burning and allergic reactions were reported by two women each.
"Also, we can put it in ahead of time. For example, if a client arrives and we already know that he doesn't like to use a condom, we can go to the bathroom a half-hour ahead of time and put it on."-San Miguel, round 1

Women also described the design of the female condom as offering greater protection than the male condom because it covers "the outer part of the vagina" and labia so that they do not have direct genital contact with their partner. They said they thought the female condom provided better protection against STIs and pregnancy than the male condom.

Women also had positive perceptions of the material of the female condom. They said it appears strong and thick, making it less likely to break than the male condom and giving them a greater feeling of security. Some women noted that they preferred the smell of the female condom to that of the male condom.

Many women in the focus group discussions reported negative reactions to the appearance and large size of the female condom, and noted the difficulty of concealing the large package:

"I got scared and I said, 'This strange thing is so big. How will I use it?"'-San Miguel, round 1

"For me, it seems like everything is okay. The only thing is that the package is large and my mom doesn't know the kind of work that I do. So how will I hide them?"-San Miguel, round 1

A few women also noted physical symptoms as barriers to use, including discomfort (especially at first), bleeding, burning and allergic reactions. * Loss of an opportunity to earn more money from clients requesting sex without a condom was also suggested as a barrier to female condom use.

\section{Access}

Access was cited as an obstacle to future female condom use, including limited availability of the device and the potential unsubsidized retail price of US\$2-3 per female condom. Women recommended that it be sold and distributed widely in the same places where male condoms are sold, and at the same price as the male condom or at no charge.

In the structured interviews, women said they would prefer that female condoms be distributed in pharmacies, clinics and hospitals, and places of employment. Women from Managua had a strong preference for pharmacy distribution, whereas women from San Miguel and San Salvador tended to prefer clinic and hospital distribution. Only women from San Salvador mentioned bars, clubs and hotels as important distribution points for female condoms. Other outlets mentioned were supermarkets, motels, gas stations, massage centers, places where they sell male condoms and "everywhere possible."

\section{Education}

Women were asked in both the focus group discussions and the structured interviews how their peers could best learn to use the female condom, including the best modes of instruction, what training should be provided and by whom, 


\begin{tabular}{|c|c|c|c|c|}
\hline \multicolumn{2}{|c|}{ Topic } & $\begin{array}{l}\text { San Salvador, } \\
\text { El Salvador }\end{array}$ & $\begin{array}{l}\text { San Miguel, } \\
\text { El Salvador }\end{array}$ & $\begin{array}{l}\text { Managua, } \\
\text { Nicaragua }\end{array}$ \\
\hline \multicolumn{5}{|c|}{ PREGNANCY AND STI INFORMATION } \\
\hline 1 & Discussed the woman's risk of STIs and HIV & 4 & 4 & 3 \\
\hline 2 & Discussed the woman's risk of becoming pregnant & 3 & 4 & 2 \\
\hline \multirow[t]{2}{*}{3} & Discussed the basic facts of HIV and AIDS (e.g., HIV is the virus that causes AIDS. & & & \\
\hline & There is no cure for AIDS.) & 4 & 4 & 3 \\
\hline 4 & Discussed using contraceptives (not including condoms) to prevent pregnancy & 4 & 4 & 1 \\
\hline \multirow[t]{2}{*}{5} & Referred woman to places where she could get a contraceptive method & & & \\
\hline & & 4 & 3 & 3 \\
\hline 6 & $\begin{array}{l}\text { Discussed dual method use (using a condom along with another method } \\
\text { to prevent STIs, HIV and pregnancy) }\end{array}$ & 3 & & 2 \\
\hline 7 & Discussed being tested and treated for STIs & 4 & 4 & 4 \\
\hline 8 & Made referral to STI testing site & 4 & 4 & 3 \\
\hline 9 & Discussed getting tested for HIV & 4 & 4 & 1 \\
\hline 10 & Made referral to voluntary counseling and testing site (for HIV) & 4 & 4 & 1 \\
\hline \multicolumn{5}{|c|}{ MALE CONDOM INFORMATION } \\
\hline 11 & Asked if woman is always able to use male condoms with new clients & $3^{*}$ & 4 & 1 \\
\hline \multirow[t]{2}{*}{12} & Asked if woman is always able to use male condoms consistently & & & \\
\hline & with regular clients & $3^{*}$ & 4 & 1 \\
\hline \multirow[t]{2}{*}{13} & Asked if woman is always able to use male condoms with nonpaying & & & \\
\hline & partners such as boyfriends and husbands & $3^{*}$ & 4 & 1 \\
\hline 14 & Offered the woman male condoms & 4 & 4 & 3 \\
\hline \multicolumn{5}{|c|}{ FEMALE CONDOM INFORMATION } \\
\hline 15 & Stated female condom is an alternative when male condoms are not used & $3^{*}$ & 4 & 2 \\
\hline 16 & Discussed ways to negotiate female condom with partner & $3^{*}$ & 4 & 3 \\
\hline 17 & Discussed benefits of female condom use & $3^{*}$ & 4 & 3 \\
\hline 18 & Mentioned that female condom can be used without partner knowledge & $3^{*}$ & 4 & 2 \\
\hline \multirow[t]{2}{*}{19} & Mentioned that female condom can be used when partner is under the & & & \\
\hline & influence of drugs or alcohol & $3^{*}$ & 4 & 1 \\
\hline 20 & Mentioned that female condoms are made of polyurethane, not latex & 4 & $3^{*}$ & 1 \\
\hline 21 & Mentioned that female condoms are thin but really strong & 4 & 4 & 2 \\
\hline 22 & Mentioned that female condoms come in one size only and fit all women & 4 & 4 & 2 \\
\hline \multirow[t]{2}{*}{23} & Encouraged woman to practice inserting the female condom before using & & & \\
\hline & it with a partner & 4 & 4 & 1 \\
\hline 24 & Explained that after practice many women find the female condom easy to insert & 4 & 4 & 2 \\
\hline 25 & Mentioned that inner ring of the female condom goes above pubic bone & 4 & 4 & 2 \\
\hline \multirow[t]{2}{*}{26} & Mentioned that woman can feel inner ring if the female condom is not & & & \\
\hline & inserted correctly & 4 & 4 & 1 \\
\hline \multirow[t]{2}{*}{27} & Mentioned that if pain or discomfort is felt, the female condom is not & & & \\
\hline & inserted correctly & 4 & 4 & $1 *$ \\
\hline 28 & Mentioned that the outer ring of the female condom remains outside the vagina & 4 & 4 & 2 \\
\hline 29 & Mentioned that the penis goes into the female condom & 4 & 4 & 2 \\
\hline 30 & Mentioned that the woman must use a new female condom for each sex act & 4 & 4 & 3 \\
\hline 31 & Mentioned that lubricants can be used with female condoms & 4 & 4 & 4 \\
\hline \multirow[t]{2}{*}{32} & Mentioned that female condoms can make sex enjoyable because they heat up & & & \\
\hline & during use & 2 & 0 & 1 \\
\hline 33 & Mentioned that female condoms can be inserted up to eight hours before having sex & 1 & 0 & 1 \\
\hline 34 & Mentioned that female condoms can prevent pregnancy if always used & 3 & 4 & 2 \\
\hline 35 & Mentioned that female condoms can reduce the risk of STIs and HIV if always used & 4 & 4 & 3 \\
\hline 36 & Asked if the woman had questions about female condoms & 4 & 4 & 1 \\
\hline 37 & Offered the woman female condoms & 4 & 4 & 1 \\
\hline
\end{tabular}

where training should take place and what instructional materials would help women learn to use the female condom.

Women had varied responses about the best way to learn to use the female condom. When asked in the structured interviews if the illustrated brochure with written instructions was sufficient for a woman to learn to use the female condom, 34 of 36 women in San Salvador, 31 of 37 women in San Miguel and 17 of 22 in Managua said it was. In the focus group discussions, some women said it might be difficult for women with low literacy to learn from the brochure alone and that clear, numbered illustrations similar to those shown on the package would be essential for women who cannot read. However, other women, includ- ing women who described themselves as having low literacy, said they could, in fact, learn by using the brochure.

Many women stated in the focus group discussions that although it was possible to learn from a brochure, they would prefer or benefit additionally from instructor-led training. Female instructors were preferred. The majority of women in the focus groups recommended a demonstration using an anatomical model or an informal education session (charla), similar to those held by PASMO's health educators, as the ideal training. The recommended number of training sessions ranged from one to five. Possible instructors included health educators, gynecologists and pharmacists. The preference for instructor-led train- 
ing was confirmed in the structured interviews: Most women in San Salvador and more than half in San Miguel and Managua responded that they would be able to learn how to use the female condom from an instructional brochure plus instructor-led training.

In the focus group discussions, we also asked women whether they could learn to insert the female condom from the illustrations on the package. Some women said it was possible to learn independently by following the illustrations. However, most women reported that the package illustrations did not give enough information for a woman to learn to use the female condom on her own.

When asked in the structured interviews if they thought instructional videos would be adequate to teach women how to use the female condom, 33 of 36 women in San Salvador responded that instructional videos only or instructional videos with additional training would suffice. Nineteen of 37 women in San Miguel and 16 of 22 women in Managua answered that instructional videos only would suffice, while 13 of 37 women and 14 of 22 in those cities, respectively, recommended instructional videos with additional training (more than one response was permitted).

Women in all groups and sites also expressed a preference for training to take place at their places of employment in order to avoid missing work and for convenience. This was confirmed in the structured interviews. Despite this preference, women in the focus group discussions listed a wide variety of locations for training, including supermarkets, health centers, hospitals, night schools, places where women do sex work, factories, beauty salons, discos, hotels, motels, massage parlors, pharmacies and nongovernmental organizations (NGOs). Across sites, women in the highest socioeconomic status group reported a lower preference than women in the other groups for individual and group training sessions at clinics and NGOs. In addition, some women in all groups expressed fear of discrimination or stigma if they were to go to a training session at an NGO, or if the NGO session included women not involved in sex work. Examples of what women said include:

"I wouldn't go. I don't know....It makes me ashamed." -Managua, round 2

"If it was a group of sex workers, yes. If they are going to mix the groups, then no. Because there is discrimination." -San Miguel, round 2

When asked how the female condom should be promoted to their peers, some women suggested that instruction or charlas that discuss sexual health could incorporate female condom instruction and promotion. Several women mentioned peer educators and television as a good way to provide instruction and promote the female condom. One group in Managua recommended a marketing campaign with television advertisements and billboards, similar to the campaign for the male condom brand Vive. Most women said that the female condom should be promoted extensively so that it is as familiar as the male condom.

When asked about barriers to use of the female con- dom, women at all sites mentioned a general lack of exposure to information about the device. Women said people had not heard of the female condom; or they had heard of it but not seen it; or possibly, they had seen it but not used it. Women said they thought that few people (themselves and the general public included) had used a female condom. Clients' lack of exposure, knowledge and awareness of the female condom was reported in the focus group discussions. Women said that because men are unfamiliar with the female condom, they may fear that it is unsafe, or may refuse to use it out of ignorance or insecurity. To overcome this lack of exposure, women strongly recommended that information be provided to both women and men in the general population.

\section{Current Female Condom Promotion}

Structured observations of health educators from PASMO were conducted at all sites (Table 2, page 153). Nearly all health education sessions in San Salvador mentioned most of the 37 educational items. Similarly, most observed health education sessions in San Miguel mentioned most of the 37 educational topics. In Managua, however, 15 of the 37 topics were mentioned in only one of the four sessions.

\section{DISCUSSION}

This study was conducted to help program managers develop strategies for promoting the female condom among sex workers in Central America. To inform program strategies, we sought to learn the preferences of Central American sex workers in learning how to use the female condom and their views on factors that could affect uptake. We also sought to document PASMO's current female condom promotion in El Salvador and Nicaragua to identify site differences and gaps in promotion.

The relative difficulty in insertion of the female condom experienced by women from Managua may be explained by Managuan women's fewer years of education and could indicate that sex workers in Managua may require more intensive education about reproductive health and female condom use than they are currently receiving. This is confirmed by the results of the direct observations, which indicate that health educators in Managua need additional training to help them cover all essential information women need to use the female condom. A list of key points such as the checklist used in the observations may be useful.

Our study identified three prerequisites for Central American sex workers' uptake of female condoms that could be useful for program planners. One prerequisite was that women need to have exposure to and knowledge about the female condom. The second prerequisite was that women need assistance acquiring the mechanical skills to use the female condom. This is consistent with the findings of a randomized controlled trial in which skills training was shown to increase female condom use and protected sex acts. ${ }^{28}$

Based on study participants' responses, we have several recommendations for how programs can address the first two key prerequisites-acquiring knowledge and mechani- 
cal skills. Women's preferences for education included 1-5 trainings led by health educators, gynecologists or pharmacists, supported by illustrated print material and demonstrations with an anatomical model. Training sessions should not include women who are not sex workers and should take place at women's place of employment or at health clinics and pharmacies. Trainers should emphasize that practice in female condom use is needed. It is recommended that women practice female condom insertion and removal at least twice before using it during intercourse with a partner, and that they should use the female condom 3-10 times during intercourse before deciding if they like it.

Promotional efforts should target women and men in the general public to increase exposure to the female condom among sex workers' partners, who would fall outside of targeted marketing to sex workers. It is possible that increasing men's familiarity with female condoms may help sex workers negotiate female condom use with partners.

The third prerequisite for female condom uptake is safe and convenient access to a supply of female condoms. Study participants recommended that a steady supply of female condoms be distributed in locations where stigma is less likely to be an issue, particularly pharmacies, clinics, hospitals and places of employment, as well as bars and hotels. Study participants also recommended that program staff provide essential information about the female condom to providers and others at distribution outlets. These results correspond with other assessments and recommendations for female condom programming in developing countries. ${ }^{20,22,27,29}$ It should also be noted that in order for a steady supply of female condoms to be available for distribution, programs need to engage in longrange planning and dialogue with donors to address the inconsistent supply of female condoms, an issue that has plagued female condom uptake from its inception. ${ }^{25,27}$

An additional recommendation from the study is that key messages for female condom promotion to sex workers in Central America could be standardized to increase uptake. The main message for first-time female condom users is that learning how to use the female condom can be challenging and takes time, as has been found in other studies. ${ }^{21,29}$ Communication of this message is essential because women may give up before they feel comfortable using the female condom.

This study had several limitations. Because of the small sample size in each site, it was not possible to draw statistically significant conclusions from the structured interview data. A second limitation is that it was difficult to retain study participants throughout the three data collection events. Finally, funding constraints precluded more extensive analysis of focus group discussion data.

\section{Conclusion}

On the basis of the focus group discussion and structured interview data, we would anticipate favorable uptake of the female condom among female sex workers in Central America, if provisions are made for instructing women on female condom use in places where women will not feel stigmatized, and if supplies are easily and consistently available. Health educators' use of promotional tools such as checklists and standardized messages is also strongly recommended. As the study participants suggested, even greater success for the female condom might be expected in Central America if promotion also occurred in the general population.

\section{REFERENCES}

1. Pintin C and Hernandez Lazo EG, Aceptación y Uso del Condón Femenino, San Salvador, El Salvador: Flor de Piedra, 2004.

2. Caal M, Valverde $\mathrm{O}$ and Pedrique B, Aceptabilidad del condón femenino entre trabajadoras comerciales del sexo de la ciudad de Guatemala, 2002, <http://74.125.155.132/scholar?q=cache: A2pSpYbaOX4J:scholar.google.com/\&hl=en\&as_sdt=40000000000>, accessed Feb. 10, 2010.

3. Madrigal J, Schifter J and Feldblum PJ, Female condom acceptability among sex workers in Costa Rica, AIDS Education and Prevention, 1998, 10(2):105-113.

4. Melendez G, Pan American Social Marketing Organization, Guatemala City, Guatemala, personal communication, June 4, 2006.

5. Deniaud F, Dynamics of female condom acceptability among prostitutes and young women in Abidjan, Ivory Coast, Contraception, Fertilité, Sexualité, 1997, 25(12):921-932.

6. Fontanet AL et al., Protection against sexually transmitted diseases by granting sex workers in Thailand the choice of using the male or female condom: results from a randomized controlled trial, AIDS, 1998, 12(14):1851-1859.

7. Welsh MJ et al., Condom use during a community intervention trial in Kenya, International Journal of STD and AIDS, 2001, 12(7):469-474.

8. Musaba E et al., Long-term use of the female condom among couples at high risk of human immunodeficiency virus infection in Zambia, Sexually Transmitted Diseases, 1998, 25(5):260-264.

9. Thomsen SC et al., A prospective study assessing the effects of introducing the female condom in a sex worker population in Mombasa, Kenya, Sexually Transmitted Infections, 2006, 82(5):397-402.

10. French PP et al., Use-effectiveness of the female versus male condom in preventing sexually transmitted disease in women, Sexually Transmitted Diseases, 2003, 30(5):433-439.

11. Drew WL et al., Evaluation of the virus permeability of a new condom for women, Sexually Transmitted Diseases, 1990, 17(2):110-112.

12. Hoke TH et al., Temporal trends in sexually transmitted infection prevalence and condom use following introduction of the female condom to Madagascar sex workers, International Journal of STD and AIDS, 2007, 18(7):461-466

13. Soper DE et al., Prevention of vaginal trichomoniasis by compliant use of the female condom, Sexually Transmitted Diseases, 1993, 20(3): $137-139$

14. Farr G et al., Contraceptive efficacy and acceptability of the female condom, American Journal of Public Health, 1994, 84(12):1960-1964.

15. Vijayakumar G et al., A review of female-condom effectiveness: patterns of use and impact on protected sex acts and STI incidence, International Journal of STD and AIDS, 2006, 17(10):652-659.

16. Agha S, Intention to use the female condom following a mass-marketing campaign in Lusaka, Zambia, American Journal of Public Health, 2001, 91(2):307-310.

17. Hoffman $S$ et al., The future of the female condom, International Family Planning Perspectives, 2004, 30(3):139-145.

18. Warren M and Philpott A, Expanding safer sex options: introducing the female condom into national programmes, Reproductive Health Matters, 2003, 11(21):130-139.

19. World Health Organization (WHO), The Female Condom: A Guide for Planning and Programming, Geneva: WHO, 2000. 
20. Peterson K et al., Smarter Programming of the Female Condom: Increasing Its Impact on HIV Prevention in the Developing World, Boston, MA, USA: FSG Social Impact Advisors, 2008.

21. Telles Dias PR, Souto K and Page-Shafer K, Long-term female condom use among vulnerable populations in Brazil, AIDS and Behavior, 2006, 10(4 Suppl.):S67-S75.

22. Mantell JE, Scheepers E and Karim QA, Introducing the female condom through the public health sector: experiences from South Africa, AIDS Care, 2000, 12(5):589-601.

23. Artz L et al., Effectiveness of an intervention promoting the female condom to patients at sexually transmitted disease clinics, American Journal of Public Health, 2000, 90(2):237-244.

24. Van Devanter N et al., Effect of an STD/HIV behavioral intervention on women's use of the female condom, American Journal of Public Health, 2002, 92(1):109-115

25. Oxfam International and World Population Fund, Failing women, withholding protection, Oxfam Briefing Paper, The Hague, Netherlands: Oxfam International and World Population Fund, 2008, No. 115.

26. Brown GF, Raghavendran V and Walker S, Planning for Microbicide Access in Developing Countries: Lessons from the Introduction of Contraceptive Technologies, Silver Spring, MD, USA: International Partnership for Microbicides, 2007

27. Center for Health and Gender Equity (CHANGE), Saving Lives Now: Female Condoms and the Role of U.S. Foreign Aid, Takoma Park, MD, USA: CHANGE, 2008

28. Choi KH et al., The efficacy of female condom skills training in HIV risk reduction among women: a randomized controlled trial, American Journal of Public Health, 2008, 98(10):1841-1848.

29. Population Council and Liverpool VCT, Care \& Treatment, FemaleInitiated Prevention: Integrating Female Condoms into HIV Risk-Reduction Activities in Kenya, Nairobi, Kenya: Population Council, 2009.

\section{RESUMEN}

Contexto: Los condones femeninos tienen un rol potencial en la reducción de la infección por VIH en trabajadoras del sexo en América Central. Se justifica la investigación sobre cómo introducir el uso de condones femeninos en esta población.

Métodos: Se llevaron a cabo dos rondas de grupos focales con trabajadoras del sexo (115 en la primera ronda y 81 en la segunda) en El Salvador y Nicaragua en 2007-2008. Además, se realizaron entrevistas estructuradas con 95 trabajadoras del sexo y se observaron directamente las actividades de seis educadores en materia de salud.

Resultados: Las mujeres reportaron que el diseño de los condones femeninos dificultaba el aprendizaje de su inserción y remoción. Cerca de un tercio de las participantes reportaron habérselo insertado por sí solas la primera vez. La mayoría de las mujeres reportaron haber practicado $2-10$ veces antes de sentirse lo suficiente preparadas para usarlos con sus clientes. Las percepciones positivas incluyeron lubricación, tamaño, comodidad y resistencia. Las percepciones negativas incluyeron el tamaño grande del empaque, incomodidad física inicial y la posibilidad de que el dispositivo pudiera ahuyentar a los clientes. Las participantes prefirieron aprender a usar los condones femeninos con un folleto instructivo apoyado con capacitación dirigida por una instructora en su centro de trabajo. Ellas citaron como barrera para el uso del condón femenino la falta de conocimiento de hombres y mujeres sobre este tipo de condón; y recomendaron actividades educativas tanto para hombres como para mujeres. También recomendaron la distribución de condones femeninos en los lugares en donde están disponibles los condones masculinos.
Conclusiones: Si se toman medidas para instruir a las trabajadoras del sexo sobre el uso del condón femenino en lugares en donde no se sentirán estigmatizadas; y si se cuenta con los suministros de manera fácil y consistente, parece probable la aceptación favorable del condón femenino entre las trabajadoras del sexo en América Central. Se recomienda ampliamente que los educadores en materia de salud usen herramientas promocionales como listas de verificación y mensajes estandarizados.

\section{RÉSUMÉ}

Contexte: Le préservatif féminin pourrait jouer un rôle dans la réduction de l'infection à VIH parmi les travailleuses du sexe d'Amérique centrale. Il serait bon d'étudier la manière d'introduire la méthode auprès de cette population.

Méthodes: Deux séries d'entretiens de groupe avec des travailleuses du sexe (115 lors du premier passage et 81 lors du second) ont été organisées au Salvador et au Nicaragua en 2007-2008. Nous avons par ailleurs mené des entrevues structurées avec 95 travailleuses du sexe et procédé à l'observation directe de six éducateurs sanitaires.

Résultats: Les femmes ont déclaré que la conception du préservatif féminin en rend l'insertion et l'enlèvement difficiles à maîtriser. Environ un tiers des participantes ont déclaré l'avoir mis en place dans des conditions où elles étaient seules lors de leur premier essai. La plupart ont dit s'être exercées deux à 10 fois avant de se sentir prêtes à l'utiliser avec leurs partenaires. Des perceptions positives ont été exprimées concernant la lubrification, la taille, le confort et la résistance. Les perceptions se sont révélées négatives concernant le grand format de l'emballage, la gêne physique initiale et le risque que la méthode fasse fuir les clients. Les participantes ont dit préférer apprendre à utiliser le préservatifféminin à l'aide d'une brochure en décrivant l'emploi et par démonstration dans le cadre d'une formation offerte dans leur milieu de travail. Elles citent le manque d'exposition des hommes et des femmes à la méthode comme obstacle à son usage et recommandent la sensibilisation des hommes comme des femmes. Elles recommandent aussi la distribution du préservatif féminin aux endroits où le préservatif masculin peut être obtenu.

Conclusions: Si des dispositions sont prises pour instruire les femmes sur l'usage du préservatifféminin dans des endroits où elles ne se sentent pas rejetées et si la méthode peut être obtenue facilement et sans interruptions, l'adoption favorable du préservatifféminin semble probable parmi les travailleuses $d u$ sexe d'Amérique centrale. Le recours des éducateurs sanitaires aux outils de promotion tels que les listes aide-mémoire et les messages normalisés est fortement recommandé.

\section{Acknowledgments}

This work was funded by the U.S. Agency for International Development (USAID) through GPO-1-07-04-00007-0, awarded to Abt Associates, Population Services International (PSI) and Family Health International. The Pan American Social Marketing Organization, PSI's Central American affiliate, provided field support and Mercaplan, Inc., conducted all data collection. The authors' views do not necessarily reflect the views of USAID.

\section{Author contact: nmack@fhi.org}

